\title{
Analysis of Water Quality in the Tabuk River Sub-Watershed, South Barito Regency
}

\author{
Nurul Fazriyanti ${ }^{1}$, M.Ruslan², Erwin Rosadi ${ }^{3}$, Agustiana $^{4}$ \\ ${ }^{1}$ Master Program in Natural and Environmental Resource Management, Lambung Mangkurat University, Indonesia \\ ${ }^{2}$ Faculty of Forestry, Lambung Mangkurat University, Indonesia \\ ${ }^{3}$ Faculty of Fisheries and Maritime Affairs, Lambung Mangkurat University, Indonesia \\ ${ }^{4}$ Faculty of Fisheries and Maritime Affairs, Lambung Mangkurat University, Indonesia
}

\begin{abstract}
The Tabuk River Sub-Watershed is a tributary of the Barito River wich is Located in the Buntok City area of South Barito Regency. The River is Located in a residential area full of river flow Tabuk indicated has increased pollution caused by community activites on the riverbanks such as CWT activities (Cook, Wash, Toilet), Fisheries and tourism. This study aims to analyze the quality of Tabuk river water based on the status of water quality that refers to the decision of the state Minister of Environment No. 115 of 2003, and formulate strategies for controlling the pollution of the Tabuk river flow. The parameters analyzed are physics, chemistry and microbiology, the quality of river water is analyzed at three sampling points during high and low tide conditions. Analysis of river water quality status using the pollution index method. The result obtained are (1) the water quality of the Tabuk River Sub-Watershed for parameters that exceed the Class II water quality standards are TSS, BOD, COD, Total Coliform, Fecal colifirm during tidal or low tide conditions. TSS parameters $382 \mathrm{mg} / \mathrm{L}$ at low tide, and $157 \mathrm{mg} / \mathrm{L}$ at high tide. The BOD parameter is $61.5 \mathrm{mg} / \mathrm{L}$ during low tide, and $9.4 \mathrm{mg} / \mathrm{L}$ at high tide. The COD parameter is $83.7 \mathrm{mg} / \mathrm{L}$ during low tide, and $74 \mathrm{mg} / \mathrm{L}$ at high tide wich indicates a decline in water quality with moderate to mild water quality status. (2) efforts and strategies for the quality of tabuk river water to be in accordance with water quality standard criteria, namely (a) monitoring and maintaining Tabuk river water quality during low tide and tide conditions, $(b)$ controlling domestic and nondomestic waste entering the river sub-watershed Tabuk, $(c)$ establishes the concept of community participation as a reference for each agency that has an interest in carrying out river management activities.

Keywords-Sub Watershed, Water Quality, Water Quality Status, Water Pollution Control.
\end{abstract}

\section{INTRODUCTION}

The life of the people of the south Barito Regency in is inseparable from the existence of the river. With a population of 134.543 people and an are of $1829 \mathrm{~km}^{2}$ (Statisticts Indonesia, 2018). Most people use river water as a source of clean water and some others use rainwater and surface water sources.

The river passes through 3 villages, namely Buntok Kota with a total of 16,621 people, which is a densely populated area. Downstream Sper with a population of 14,738 people, is a residential area, where the river is used by the community as a place of fishing in the river body, namely the existence of several fishponds around the river. Pamait with a population of 862 people, which is a small residential area and is used by the community as a place for bathing tourism.

Statistics from the South Dusun District, 2017 states that the number of houses living along the river is 217 houses in Buntok Kota, 79 houses in Hilir Sper, and 70 houses in Pamait. The average community that lives around the Tabuk riverbank has a place to stay facing the river, As a result, the potential of the community to dispose of garbage into the river is getting bigger, especially in gray water and black water waste as well as washing activities of BWT (Bathing, Washing, and Toilet) which can potentially produce liquid waste entering the river body.

Increased activity around the river can cause a decrease in the quality and quantity of the river. Water quality is a term to describe the suitability or suitability of water for certain uses, such as drinking water, fisheries, irrigation / irrigation, recreation and so on (Juanda, 2014). Besides the lack of knowledge, and research and public awareness of the condition of polluted rivers can cause the river does not meet quality standards or can not be used for certain needs, which will ultimately affect the surrounding community in using river water as daily necessities.

Maintaining or achieving water quality so that it can be used sustainably in accordance with the desired level of water quality, it is necessary to preserve and or 
control efforts. Preservation of water quality is an effort to maintain the function of water so that the quality remains at its natural condition. Water pollution control is carried out to guarantee water quality to conform to water quality standards through efforts to prevent and control water pollution and to restore water quality.

\section{RESEARCH METHOD}

The study was conducted using descriptive data analysis explaining the water quality and quality status of the Tabuk River Sub-Watershed. Water quality research was conducted at three monitoring points by dividing into two segments namely at low tide and tide, the following 3 (three) monitoring points for sampling the Tabuk River watershed in this study (Figure 1). As follow:

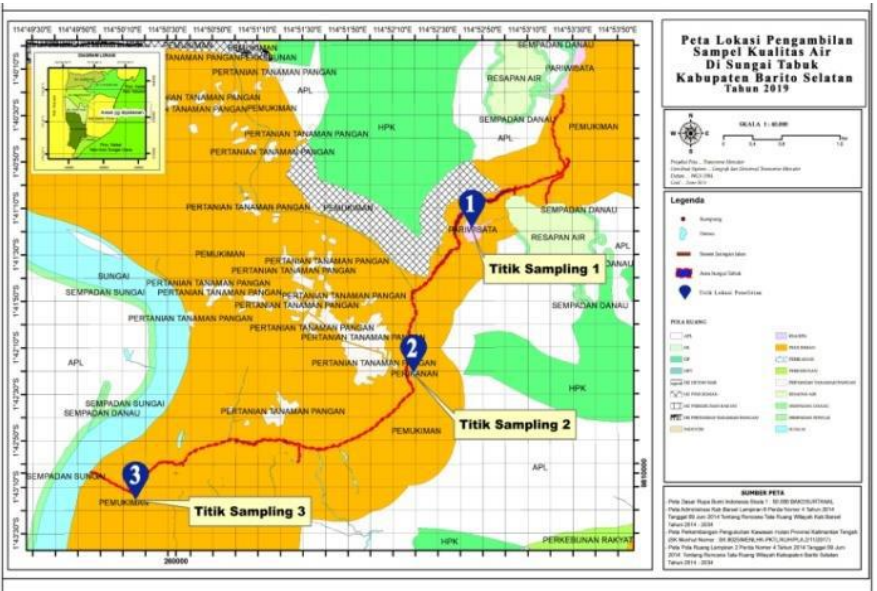

Fig.1: Sampling Location

The sampling method used is the Grab Sampling method, the method of taking samples for a moment that is directly taken from the body of water being monitored (Effendi, 2003). The sampling point is based on SNI procedures. 57. 6989. 2008 which can be seen in Table 1.
Table 1. Parameters and Methods for Testing Water

\begin{tabular}{|c|c|c|}
\hline \multicolumn{3}{|c|}{ Samples } \\
\hline & Parameter & Metode \\
\hline 1 & $\begin{array}{l}\text { BOD (Biochemical } \\
\text { Oxygen Demond) }\end{array}$ & SNI 6989.72:2009 \\
\hline 2 & $\begin{array}{l}\text { COD (Chemical } \\
\text { Oxygen Demand) }\end{array}$ & SNI 6989.73:2009 \\
\hline 3 & $\begin{array}{l}\text { TSS (Total Suspended } \\
\text { Solid) }\end{array}$ & SNI 6989.03:2004 \\
\hline 4 & Total Coliform & SNI 2897:2008 \\
\hline 5 & Fecal Coliform & SNI 2322:2006 \\
\hline
\end{tabular}

Analysis of water quality of the Tabuk River SubWatershed using Class II water quality criteria according to Government Regulation of the Republic of Indonesia Number 82 Year 2001 concerning Water Quality Management and Water Pollution Control. And the status of water quality is determined using the Pollution Index method in accordance with the Minister of Environment Decree No.115 of 2003. The Pollution Index calculation is performed by the calculation procedure using the equation:

$$
\mathrm{PI}_{\mathrm{j}}=\sqrt{\frac{\left(\frac{C i}{L i j}\right) \frac{2}{M}-\left(\frac{C i}{L i j}\right) \frac{2}{R}}{2}}
$$

where Lij: concentration of water quality parameters stated in Water Designation Standards (j) and Ci: concentration of water quality parameters (i), PIj is Pollution Index for designation (j), With (Ci / Lij) R: value, Ci / Lij average and ( $\mathrm{Ci} / \mathrm{Lij}$ ) $\mathrm{M}$ : value, maximu $\mathrm{m} \mathrm{Ci} / \mathrm{Lij}$.

The data analysis method used in formulating a strategy for controlling pollution in the Tabuk River SubWatershed is a SWOT (Strength, Weakness, opportunity, Treat) analysis. SWOT analysis is the systematic identification of various factors to formulate a management plan (3).

\section{RESULT AND DISCUSSION}

\section{1) Analysis of Water Quality in the Tabuk River} Sub-Watershed

The results of water quality measurements on BOD, COD, TSS, total Coliform and fecal coliform at each monitoring point are compared with Class II river water quality criteria. As seen in Table 2 about the analysis of water quality at high tide and Table 3 at low tide conditions.

Table 2. Laboratory Analysis Results of the Tabuk River Sub-watershed during tidal conditions

\begin{tabular}{clccccc}
\hline \multirow{2}{*}{ No. } & \multirow{2}{*}{ Parameter } & \multirow{2}{*}{ Satuan } & Hulu & $\begin{array}{c}\text { Sungai Tabuk } \\
\text { Tengah }\end{array}$ & Hilir & $\begin{array}{c}\text { Baku Mutu } \\
\text { Kelas II }\end{array}$ \\
\hline 1 & TSS $^{* *}$ & $\mathrm{mg} / \mathrm{l}$ & $92^{\mathrm{b}}$ & $113^{\mathrm{b}}$ & $157^{\mathrm{b}}$ & 50 \\
2 & BOD $*^{*}$ & $\mathrm{mg} / \mathrm{l}$ & $7^{\mathrm{b}}$ & $7.6^{\mathrm{b}}$ & $9.4^{\mathrm{b}}$ & 3 \\
3 & COD $^{*}$ & $\mathrm{mg} / 1$ & $40^{\mathrm{b}}$ & $68.7^{\mathrm{b}}$ & $74^{\mathrm{b}}$ & 25 \\
4 & Total Coliform & $\mathrm{MPN} / 100 \mathrm{ml}$ & $1700^{\mathrm{a}}$ & $2200^{\mathrm{a}}$ & $1300^{\mathrm{a}}$ & 5000 \\
5 & Fecal Coliform & $\mathrm{MPN} / 100 \mathrm{ml}$ & $330^{\mathrm{a}}$ & $1400^{\mathrm{b}}$ & 330 & 1000 \\
\hline
\end{tabular}


Table 3. Results of Laboratory Analysis of the Tabuk River Watershed during low tide

\begin{tabular}{clccccc}
\hline No. & \multirow{2}{*}{ Parameter } & Satuan & Hulu & $\begin{array}{c}\text { Sungai Tabuk } \\
\text { Tengah }\end{array}$ & Hilir & Baku Mutu Kelas \\
\hline 1 & TSS & $\mathrm{mg} / \mathrm{l}$ & $156^{\mathrm{b}}$ & $241^{\mathrm{b}}$ & $382^{\mathrm{b}}$ & 50 \\
2 & BOD & $\mathrm{mg} / 1$ & $8.80^{\mathrm{b}}$ & $14.3^{\mathrm{b}}$ & $61.5^{\mathrm{b}}$ & 3 \\
3 & COD & $\mathrm{mg} / 1$ & $43^{\mathrm{b}}$ & $66.8^{\mathrm{b}}$ & $83.7^{\mathrm{b}}$ & 25 \\
4 & Total Coliform & MPN/100ml & $700^{\mathrm{a}}$ & $1400^{\mathrm{a}}$ & $24000^{\mathrm{b}}$ & 5000 \\
5 & Fecal Coliform & MPN/100ml & $170^{\mathrm{a}}$ & $790^{\mathrm{a}}$ & $13000^{\mathrm{b}}$ & 1000 \\
\hline
\end{tabular}

\section{Total Suspendied Solid (TSS)}

Analysis of the TSS parameters shows that the TSS concentration has increased to exceed the limits of the specified water quality standard. The increase in the value of TSS is due to the downstream so many land use changes become densely populated areas so that the community activities there in also increase which causes soil solids entering.

Habits of the community that function as a place for bathing, washing, toilet (BWT) and as fisheries and rubbish dumped directly into the river will pile upstream, causing the highest TSS value in the downstream of the Tabuk river.

\section{Biochemical Oxygen Demand (BOD)}

Tests on BOD parameters are known to increase from upstream to downstream and during low tide conditions it is known that BOD values are higher than BOD values at high tide. This indicates that the Tabuk river water has been polluted by waste disposal, both waste originating from tourism, fishery activities, and domestic waste generated by community activities along the river banks.

The results of the BOD test during low tide and tide conditions when compared with the class II water quality standards have passed the quality standard limit of $3 \mathrm{mg} / \mathrm{l}$. the greater levels of BOD indicate that the indicated waters have been polluted especially in the downstream areas at low tide of $61.5 \mathrm{mg} / 1$. the increase in BOD value at low tide can be caused by the disposal of organic waste originating from household waste where it is known that the downstream area is a densely populated area on the banks of the river and many of the houses make the kitchen enter the river, so that the direct household waste water goes directly to the river. In addition, the existence of aquaculture and leftover food derived from aquaculture also affects the high content of BOD. Organic wastes are generally in the form of waste that can rot or be degraded by microorganisms so that when discharged into water it will increase BOD (4).

\section{Chemical Oxygen Demand (COD)}

COD concentration levels showed an increase from upstream to downstream both at low tide and at high tide. Increased levels of COD from upstream to downstream, can indicate that the Tabuk river water has been polluted due to waste disposal from upstream, where the upstream area is an area that contributes organic and non organic waste due to tourism activities. Then the flow of river water flows to the middle area where there is community activity in fish farming that can cause COD content to increase, because in these activities there is feeding which can cause the accumulation of leftover feed in the river which will eventually rot.

In the downstream areas there was a high increase of $74 \mathrm{mg} / 1$ during high tide conditions and $83 \mathrm{mg} / 1$ during low tide conditions this could be due to increased domestic waste disposal in downstream areas and is a densely populated area along the river. The high value of COD in waters is caused by the large amount of pollutants entering the waters, especially organic pollutants from household waste and aquaculture (5).

\section{Total Coliform}

The total coliform when tested was known when the tide conditions ranged from 1300-2200 MPN/100 ml from upstream to downstream. In these areas still meet the water quality standards for class II. So that for the touris $m$ and fisheries areas it is still safe to be used as a cultivation and tourism activity. If it exceeds grade II water quality standards, it will cause disease both for tourism and fish farming. Because for fish farming must also pay attention to environmental health in order to be safe for consumption of fish. Success in fish farming is from maintaining environmental health from bacterial diseases (6). Communities that build latrines in rivers will cause rivers to be polluted with human excrement higher by indicating high total coliforms (7). The bacterial density indicates the suitability of water for drinking water, recreation, and fisheries.

Fecal Coliform 
The bacterial density indicates the suitability of water for drinking water, recreation, and fisheries. Where the results are compared with the class II water quality standard of $1000 \mathrm{MPN} / 100 \mathrm{ml}$ it has exceeded the water quality standard set by Government Regulation No. 82 of 2001.

If it is found that the density of bacteria exceeds the quality standard threshold, then the waters are not suitable for cultivation activities because they can cause mass death of the seeds and a decrease in the quality of post-harvest biota (8). Bacterial content is influenced by the volume of water, when the volume of water is high it has a lower bacterial content compared to when the volume of water drops (9).
2). Quality Status Analysis of the Tabuk River Sub Watershed

The test results from the Tabuk river water samples, it is known that parameters that exceed the Class II water quality standards are TSS, BOD, COD, Total Coliform, Fecal coliform during tidal or low tide conditions.

The test results of the Tabuk river water samples at high tide and low tide the river pollution status using. Pollution Index calculation is the quality of tabuk river water when the tidal conditions are mild polluted, while the status of Tabuk river water quality at low tide conditions is mild polluted in the upstream and middle regions, however, in the downstream area the status is moderate, which can be seen in Table 4.

Table 4. Water Quality Status Value Value Based on Pollution Index

\begin{tabular}{lcl}
\hline Sampling Point & Pollution Index & Category \\
\hline Upstream When Tide & 1,55 & Light Pollution \\
Middel When Tide & 2,51 & Light Pollution \\
Downstrean When Tide & 2,77 & Light Pollution \\
Upstream At Low Tide & 1,86 & Light Pollution \\
Middle At Low Tide & 2,99 & Light Pollution \\
Downstream At Low Tide & 5,30 & Light Pollution \\
\hline
\end{tabular}

The level of pollution obtained based on calculations is known that the condition of the Tabuk river water at low tide is higher than during tidal conditions. This is due to the condition of the water when the tide has high water discharge and high rainfall can also cause dilution so that it can reduce the level of pollution. Whereas during low tide the water has a low flow of water and the flow of community waste goes directly to the river which will flow from upstream to downstream so that it is piled upstream downstream, this can cause pollution in the downstream area.

Table 5. Analysis of Efforts to Control Water Pollution in the Tabuk River Sub-Watershed

\begin{tabular}{|c|c|c|}
\hline (1) & $\begin{array}{l}\text { River Water } \\
\text { Pollution Control } \\
\text { Aspects } \\
\text { (2) }\end{array}$ & Indicator \\
\hline 1. & $\begin{array}{l}\text { Condition of the } \\
\text { Tabuk River }\end{array}$ & $\begin{array}{l}\text { 1. In general, Tabuk river water quality class II water criteria on certain parameters } \\
\text { when the tidal conditions have exceeded the water quality standard } \\
\text { 2. The status of Tabuk river water quality is mildly or moderately polluted. } \\
\text { 3. When the Tabuk river water conditions install some parameters such as COD, } \\
\text { BOD, TSS have exceeded the pollution load capacity. }\end{array}$ \\
\hline 2. & $\begin{array}{l}\text { Role of the } \\
\text { Government }\end{array}$ & $\begin{array}{l}\text { 1. There is a related SKPD in charge of waste water management. } \\
\text { 2. The existence of a complaint center for pollution cases at environmental } \\
\text { agenciesi } \\
\text { 3. Supporting Information and data relating to the Tabuk River watershed and it's } \\
\text { pollution control are still incomplete condition of the Tabuk River }\end{array}$ \\
\hline
\end{tabular}

\section{3). Formulation of River Water Pollution Control Strategies}

Water Pollution Control is an effort to prevent and control water pollution and water recovery to ensure water quality in accordance with water quality standards (10). Based on the results of the water quality testing of the Tabuk River Sub-Watershed, interviews and literature studies, it can be described and presented in Table 5 as follows: 
3. Community Role 1. Lack of awareness from the the community in managing river cleanliness

2. People still throw garbage in the Tabuk river

Source: Primary and Secondary Data Analysis, 2019

The results of the strategies above, the policies to support the management of the Tabuk river water must involve the community and the government in paying attention to the sustainability of natural resources, such as:

1) Monitoring and maintaining water quality in the Tabuk River Sub-Watershed during low tide and tidal conditions at many community activities.

2) Control of domestic and non-domestic waste entering the Tabuk River Sub-WaterShed. Such as the socialization and construction of sewerage in residential areas that are covered by rivers.

3) Establish the concept of community participation as a reference for each agency that has an interest in carrying out river management activities. Further research can be done related to community behavior patterns that exist around the Tabuk River SubWatershed

\section{CONCLUSION}

\section{CONCLUSION AND SUGGESTION}

1. The condition of water quality in the Tabuk River Sub-Watershed that the parameters that exceed grade II water quality standards are TSS, BOD, COD, Total Coliform, Fecal coliform during tidal or low tide conditions.

2. Pollution status in river Sub-Watershed at the upstream sampling point at high tide shows mild pollution, the middle sampling point at high tide indicates light pollution, the downstream sampling point at high tide shows mild contamination, the upstream sampling point at low tide indicates light polluted. the middle sampling point at low tide shows mild pollution, the downstream sampling point at low tide shows medium polluted.

3. The strategy for controlling the pollution of the Tabuk River Sub-Watershed is to monitor and maintain the water quality of the Tabuk River during low tide and tide conditions.
4. controlling domestic and non-domestic waste entering the Tabuk Sub-Watershed, establishes the concept of community participation.

\section{SUGGESTION}

Further research can be done related to community patterns that exist in the Tabuk river Sub watershed.

\section{REFERENCES}

1) Juanda, Ari. (2014). Effect of Land Use on Water Quality in the Krueng Jreu Sub-watershed Krueng Aceh watershed, Aceh Besar Regency. Research Proposal for the Agriculture Program at Sy ah Kuala University, Banda Aceh.

2) Effendi, H. (2003). Water Quality Study for Resource Management and. Aquatic Environment. Fifth Matter. Yogjakarta : Kanisius

3) Kordi, M.G. (2010). Complete Guide to Maintaining Fresh Fish in a Tepal Pool. ANDI, Yogy akarta

4) Rahmawati, Dazy. (2011). The Influence of industrial Activities on the Quality of River Water Represented in Bergas, Semarang Regency And Efforts to Control River Water Pollution. Tesis, Undip

5) Mahyudin, et all. (2015). Analysis of Water Quality and Metro River Water Pollution Control Strategies in Kepanjen City, Malang Regency. Journal-PAL, Vol. 6, No.2, 2015

6) Sinulinga, Roland. (2015). Water Resources Management for Tourism Development on Pari Island, Kepulauan Seribu, DKI Jakarta. Water Resources Management for Tourism Development on Pari Island, Kepulauan Seribu, DKI Jakarta. Indonesian Geographic Magazine Vol. 29, No. 2 September 2015

7) Deasy, Arysanti. (2018). Analysis of Fecal Coliform Bacteria Content in Kuin River Banjarmasin City. Indonesian Geography Magazine 31 (2).

8) Pevita, et al. (2016). Study of Determination of River Pollution Load Capacity Due to Domestic Waste Discharge (Case Study of Surabaya River - Wonokromo District). Journal of Natural Resources and the Environment.

9) Andriano. (2018). Monitoring the Number of Coliform Bacteria in Lampung Province River Waters. Agro Industrial Technology Magazine (Tegi) 10 (1)

10) Ministry of Environment. (2003). Decree of the State Minister, Guidelines for Determining the Capability of Water Pollution Loads at Water Sources. 